\title{
SYNTHESIS OF NEW NITROGEN-CONTAINING DRIMANE AND HOMODRIMANE SESQUITERPENOIDS FROM SCLAREOLIDE
}

\author{
Lidia Lungu \\ Institute of Chemistry of Academy of Sciences of Moldova, 3 Academiei str., Chisinau, MD-2028, Republic of Moldova \\ e-mail: lidialungu@ymail.com
}

\begin{abstract}
The synthesis of new nitrogen-containing drimane and homodrimane sesquiterpenoids in cycle B is reported. A comparative study of the microwave (MW) assisted synthesis of drimenone versus classical conditions has been done. The drimanic and homodrimanic oximes were prepared on the base of ketones derived from commercially available sclareolide. The drimanic amine was obtained by reduction of corresponding oxime with $\mathrm{LiAlH}_{4}$. The structure of novel compounds was confirmed using IR, ${ }^{1} \mathrm{H}$ and ${ }^{13} \mathrm{C}$ NMR analyses.
\end{abstract}

Keywords: synthesis, sesquiterpenoids, oxime, reduction, 7-amino-drim-8(9)-ene.

Received: September 2015/ Revised final: October 2015/Accepted: October 2015

\section{Introduction}

Drimane and homodrimane sesquiterpenoids are classes of natural products with a broad spectrum of biological activities, including antifungal, antibacterial, antiviral, cytotoxic, antifeedant, and others [1]. The presence of nitrogen in a molecule is usually accompanied either by the appearance of new activities or by intensification of the original activity characteristic for the native terpenoids.

So far, some drimanic and homodrimanic amines have been synthesized. Urones et al. [2] prepared dihydroxyamine 1 and its derivatives, Barrero et al. [3] - hydroxylamine 2 and products of amino and/or hydroxy group derivatization (Figure 1). Later, 11-aminodrim-7-ene 3 was synthesized from drimenol 4 [4-6]. Recently, 12-amino-11dihomodrim-8-ol 5 and products 6 and 7 of its dehydration have been synthesized from sclareolide 8 [7] and 13-amino14,15-dinorlabd-8(9)-ene 9 from sclareol 10 [8] (Figure 1).

In scientific literature there are few examples about syntheses of cycle B functionalized drimanic and homodrimanic amines [2]. Thus, the aim of this research is the synthesis of drimanic and homodrimanic compounds with nitrogen containing functional groups in cycle B.<smiles>C[C@]1(I)CCC[C@@]2(C)[C@H]1CC=C(CO)[C@]2(N)CO</smiles><smiles>CC1=C(CC(C)N)C2(C)CCCC(C)(C)C2CC1</smiles>

6<smiles>CC1(C)CCC[C@@]2(C)[C@H]1CC[C@](C)(O)[C@@H]2CN</smiles><smiles>CC1=CCC2C(C)(C)CCC[C@]2(C)C1CC(C)N</smiles><smiles>CC1=CCC2C(C)(C)CCC[C@]2(C)[C@H]1CN</smiles>

3<smiles></smiles><smiles>CC1=CCC2C(C)(C)CCC[C@]2(C)[C@H]1CO</smiles>

4<smiles>CC1=C(CCC(C)N)[C@]2(C)CCC[C@](C)(O)C2CC1</smiles>

9<smiles>CC(N)C[C@@H]1[C@@](C)(O)CC[C@H]2C(C)(C)CCC[C@]21C</smiles>

5<smiles>C=C[C@](C)(O)CCC1C(C)[C@]2(C)CCCC(C)(C)C2CC[C@]1(C)O</smiles>

10

Figure 1. Norlabdanic amines and their precursors.

\section{Results and discussion}

Herein we report the preparation of new nitrogen-containing drimane and homodrimane sesquiterpenoids in cycle B (Scheme 1).

As starting material for the synthesis of the reported compounds methyl 7-oxo-13,14,15,16-tetranorlabd-8en-12-oate 11 was used, obtained in two steps in 76\% overall yield from the commercially available sclareolide 8 [9] (Scheme 1). Drim-8-en-7-one 12 can be obtained from ketoester 11 by known method as depicted in Scheme 1(a) as in [10]. We prepared compound 12 from the same ester 11 using MW irradiation (Scheme 1(b)) in the same 98\% yield but two times faster.

Drimene oxime 13 was prepared by the reaction of drim-8-en-7-one 12 with hydroxylamine hydrochloride in a mixture of ethanol:pyridine (1:1) in 98\% yield as in [11]. 
<smiles>[Y4][C@]1(C)CCC[C@]2(C)C(C)=C(C)C(N)C[C@H]12</smiles><smiles>CC(C)C</smiles><smiles>CC(=O)CC1=C(C)C(=O)C[C@@H]2C(C)(C)[C@@H](C)CC[C@@]12C</smiles>
8 11<smiles>CC(=O)CC1=C(C)C(=NO)CC2C(C)(C)CCC[C@]2(C)C1CCOO</smiles>

Scheme 1. Synthesis of nitrogen-containing drimane and homodrimane sesquiterpenoids.

Reagents and conditions: a) $\mathrm{KOH}, \mathrm{EtOH}$, reflux, 3h, 98\%; b) $\mathrm{KOH}, \mathrm{EtOH}, \mathrm{MW}, 1.5 \mathrm{~h}, 98 \%$; c) $\mathrm{NH}_{2} \mathrm{OH} \cdot \mathrm{HCl}$, EtOH, Py, 24h, 96-98\%; d) $\mathrm{LiAlH}_{4}$, THF, 5h-24h, 51-60\%; e) KOH, MeOH, 95\%.

The desired product, 7-amino-drim-8(9)-ene 14, was obtained in 51\% yield by refluxing oxime 13 with $\mathrm{LiAlH}_{4}$ in anhydrous THF as in [8]. The structure of compound $\mathbf{1 4}$ was confirmed by IR, ${ }^{1} \mathrm{H}$, and ${ }^{13} \mathrm{C}$ NMR data.

In another case, ketoester $\mathbf{1 1}$ was treated with hydroxylamine hydrochloride in a mixture of ethanol:pyridine (1:1), giving ester oxime 15 described in [11], which was subsequently saponificated with $\mathrm{KOH}$ in methanol into the oxime 16 in $95 \%$ yield.

Oximes 15 and 16 were reduced with $\mathrm{LiAlH}_{4}$ in anhydrous THF as in [8], giving two compounds: hydroxy oxime 17, in $55 \%$ and $60 \%$ yield and hydroxy ketone 18 , in $10 \%$ and $12 \%$ yield. The structure of compound 17 was confirmed by IR, ${ }^{1} \mathrm{H}$, and ${ }^{13} \mathrm{C}$ NMR data.

Several attempts to reduce oximic functions from molecules of compounds $\mathbf{1 5}$ and $\mathbf{1 6}$ were unsuccessful, probably because of steric impediments which appear in the molecules of the mentioned homodrimanic oximes $\mathbf{1 5}$ and 16, but not in the molecules of drimanes.

\section{Conclusion}

Novel nitrogen-containing drimane and homodrimane sesquiterpenoids in cycle B were synthesized. They are of scientific interest as compounds with potential biological activity.

\section{Experimental}

\section{General experimental procedure}

Melting points (m.p.) were taken on a Boetius hot stage apparatus. Optical rotations were determined on a Jasco DIP 370 polarimeter with a $1 \mathrm{dm}$ microcell, in $\mathrm{CHCl}_{3}$. IR spectra were obtained on Spectrum-100FT-IR spectrometer (Perkin-Elmer) with ATR technique.

${ }^{1} \mathrm{H}$ and ${ }^{13} \mathrm{C}$ NMR spectra were recorded in $\mathrm{CDCl}_{3}$ on Bruker Avance DRX 400 spectrometer. Chemical shifts are given in ppm in $\delta$ scale and referred to $\mathrm{CHCl}_{3}\left(\delta_{\mathrm{H}}\right.$ at $\left.7.26 \mathrm{ppm}\right)$ and to $\mathrm{CDCl}_{3}\left(\delta_{\mathrm{C}} 77.00 \mathrm{ppm}\right)$, respectively. Coupling constants $(J)$ are reported in Hertz (Hz). The H, H-COSY, H, C-HSQC and H, C-HMBC experiments were recorded using standard pulse sequences, in the version with $z$-gradients, as delivered by Bruker Corporation. Carbon substitution degrees were established by the DEPT pulse sequence.

The microwave assisted (MW) transformations were carried out using a monomode reactor (800W, STAR SYSTEM-2, under a constant irradiation power, but at varying temperature. The best results were obtained when $30 \%$ of the full power of the magnetron was used. 
For analytical TLC, Merck silica gel plates $60 \mathrm{G}$ in $0.25 \mathrm{~mm}$ layers were used. The TLC plates were sprayed with conc. $\mathrm{H}_{2} \mathrm{SO}_{4}$ and heated at $80^{\circ} \mathrm{C}$. Column chromatography was carried out on Across silica gel (60-200 mesh) using petroleum ether (PE) (b.p. $40-60^{\circ} \mathrm{C}$ ) and the gradient mixture of $\mathrm{PE}$ and EtOAc or the gradient mixture of methanol and $\mathrm{CHCl}_{3}$.

All solvents were purified and dried by standard techniques before use. Solutions in organic solvents were dried over anhydrous $\mathrm{Na}_{2} \mathrm{SO}_{4}$, then filtered and evaporated under a reduced pressure.

\section{General procedure of drimenone 12 preparation under microwave irradiation}

Caution! It is hazardous to rapidly heat reactions under microwave irradiation. Therefore, caution should be exercised when conducting reactions of this type.

A solution of ketoester $11(1 \mathrm{~g}, 3.6 \mathrm{mmol})$ and potassium hydroxide $(4.17 \mathrm{~g}, 74.3 \mathrm{mmol})$ in ethanol $(36 \mathrm{~mL})$ was prepared as described in [10] and placed in the reaction vessel (quartz). The tube was then placed in the microwave cell and irradiated at $240 \mathrm{~W}$ for $1.5 \mathrm{~h}$. Once the heating cycle was complete, the tube was cooled to ambient temperature and removed from the reactor. The $2 / 3$ of the solvent volume were removed under a reduced pressure, then the residue was diluted with water $(15 \mathrm{~mL})$, extracted with $\mathrm{Et}_{2} \mathrm{O}(3 \times 10 \mathrm{~mL})$, and the organic layer was washed with water $(2 \times 20 \mathrm{~mL})$ and dried. After the solvent removal, drim-8(9)-en-7-one 12 (0.776 mg, $98 \%)$ was obtained, as white crystals m.p. 51$52^{\circ} \mathrm{C}$. The spectral data of compound $\mathbf{1 2}$ are in accordance with those mentioned in [10].

\section{General procedure of drimanic and homodrimanic oximes preparation}

A solution of $11(0.57 \mathrm{~g}, 2.5 \mathrm{mmol})$, or $12(0.7 \mathrm{~g}, 2.5 \mathrm{mmol})$ in EtOH $(5 \mathrm{~mL})$ and Py $(5 \mathrm{~mL})$ was treated with $\mathrm{NH}_{2} \mathrm{OH} \cdot \mathrm{HCl}(0.2 \mathrm{~g})$. The resulted mixture was stirred for $24 \mathrm{~h}$ at room temperature, then diluted with water $(20 \mathrm{~mL})$ and extracted with $\mathrm{Et}_{2} \mathrm{O}(3 \times 10 \mathrm{~mL})$. The organic layer was washed with $10 \% \mathrm{HCl}(10 \mathrm{~mL}), \mathrm{NaHCO}_{3}$ solution $(10 \mathrm{~mL})$ and water $(15 \mathrm{~mL})$, dried over anhydrous $\mathrm{Na}_{2} \mathrm{SO}_{4}$ and filtered. The solvent removal under a reduced pressure as in [11] led to oximes $\mathbf{1 3}(0.59 \mathrm{~g}, 98 \%)$ or $\mathbf{1 5}(0.72 \mathrm{~g}, 98 \%)$, as white solids.

7-Hydroxyimino-drim-8(9)-ene (13), 98\% yield, as a white solid (EtOH), m.p. $183-184{ }^{\circ} \mathrm{C},[\alpha]_{\mathrm{D}}{ }^{20}=-35.5^{\circ}$ (c 13.5, $\mathrm{CHCl}_{3}$ ). IR (ATR)v : 3257, 2930, 1626, 1614, 1439, 950, 928, $772 \mathrm{~cm}^{-1} .{ }^{1} \mathrm{H}$ NMR $\left(\mathrm{CDCl}_{3}, 400 \mathrm{MHz}, \mathrm{ppm}\right)$ : $\delta 9.85(1 \mathrm{H}, \mathrm{s}, \mathrm{N}-\mathrm{OH}) ; 1.37(1 \mathrm{H}, \mathrm{d}, J 14.0 \mathrm{~Hz}, \mathrm{H}-5) ; 1.86(3 \mathrm{H}, \mathrm{s}, \mathrm{H}-12) ; 1.81$ (3H, s, H-13), 0.98 (9H, s, H-13, H-14, $\mathrm{H}-15) .{ }^{13} \mathrm{C}$ NMR (CDCl $\left., 100 \mathrm{MHz}, \mathrm{ppm}\right): \delta 158.44$ (C-7), 151.13 (C-9), 122.36 (C-8), 48.26 (C-5), 41.73 (C-3), 39.02 (C-10), 36.60 (C-1), 33.31 (C-4), 32.76 (C-14), 21.25 (C-13), 20.90 (C-6), 18.84 (C-2), 17.78 (C-15), 13.78 (C-11), $13.25(\mathrm{C}-12)$.

Methyl-7-hydroxyimino-homodrim-8(9)-en-12-oate (15), 98\% yield, as a white solid (EtOH), m.p. 130$131^{\circ} \mathrm{C},[\alpha]_{\mathrm{D}}{ }^{20}=+27.9^{\circ}\left(c 8.5, \mathrm{CHCl}_{3}\right)$. IR (ATR) $v: 3257,2928,1739,1725,1629,1435,1322,1247,1161,955,762$ $\mathrm{cm}^{-1} ;{ }^{1} \mathrm{H}$ NMR $\left(\mathrm{CDCl}_{3}, 400 \mathrm{MHz}, \mathrm{ppm}\right): \delta 9.39(1 \mathrm{H}, \mathrm{s}, \mathrm{N}-\mathrm{OH}) ; 3.29(1 \mathrm{H}, \mathrm{d}, J 16.8 \mathrm{~Hz}, \mathrm{H}-11) ; 3.19(1 \mathrm{H}, \mathrm{d}, J 16.8 \mathrm{~Hz}$, $\mathrm{H}-11) ; 1.44(1 \mathrm{H}, \mathrm{d}, J 14.4 \mathrm{~Hz}, \mathrm{H}-5)$; 3.69 (3H, s, CO Me); 1.82 (3H, s, H-13), 0.95 (9H, s, H-14, H-15, H-16). ${ }^{13} \mathrm{C}$ NMR $\left(\mathrm{CDCl}_{3}, 100 \mathrm{MHz}, \mathrm{ppm}\right): \delta 171.93$ (C-12), 158.17 (C-7),146.57 (C-9), 127.10 (C-8), 51.99 (C-17), 48.12 (C-5), 41.54 (C-3), 39.21 (C-10), 35.18 (C-1), 33.60 (C-11), 33.31 (C-4), 32.66 (C-15), 21.27 (C-14), 20.83 (C-6), 18.71 (C-2), 18.38 (C-16), 13.59 (C-13).

Synthesis of 7-amino-drim-8(9)-ene (14). A solution of oxime $13(0.5 \mathrm{~g}, 2.1 \mathrm{mmol})$ in anhydrous THF (40 $\mathrm{mL}$ ) was treated with $\mathrm{LiAlH}_{4}(0.84 \mathrm{~g})$. The resulted mixture was refluxed and stirred for $10 \mathrm{~h}$, then it was diluted with water $(20 \mathrm{~mL})$, and treated dropwise with $\mathrm{HCl}(10 \%, 20 \mathrm{~mL})$ until the acidic level of $\mathrm{pH}$ is reached. The aqueous layer was extracted with $\mathrm{Et}_{2} \mathrm{O}(2 \times 20 \mathrm{~mL})$, neutralized with the aqueous saturated $\mathrm{Na}_{2} \mathrm{CO}_{3}$ solution $(20 \mathrm{~mL})$ and extracted with EtOAc $(3 \times 15 \mathrm{~mL})$. The organic layer was washed with water $(20 \mathrm{~mL})$ and dried. After the solvent removal, the crude product $(0.35 \mathrm{~g})$ was purified by column chromatography on silica gel $\left(10 \mathrm{~g}\right.$, eluent: methanol/ $\left.\mathrm{CHCl}_{3} 1: 9\right)$ to give 7-amino-drim-8(9)-ene (8) (0.24 g, 51\%), as an oil, $[\alpha]_{\mathrm{D}}^{20}=+17.6^{\circ}\left(c 2.7, \mathrm{CHCl}_{3}\right)$.

IR (ATR)v : 3279, 2924, 1569, 1459, 1442, 1383, $1367 \mathrm{~cm}^{-1}$.

${ }^{1} \mathrm{H}$ NMR $\left(\mathrm{CDCl}_{3}, 400 \mathrm{MHz}, \mathrm{ppm}\right): \delta 3.16(1 \mathrm{H}, \mathrm{s}, \mathrm{H}-7) ; 2.07\left(2 \mathrm{H}, \mathrm{s}, \mathrm{NH}_{2}\right) ; 1.59(3 \mathrm{H}, \mathrm{s}, \mathrm{H}-12) ; 1.49(3 \mathrm{H}, \mathrm{s}$, $\mathrm{H}-11), 0.96$ (3H, s, H-15), 0.86 (3H, s, H-13), 0.82 (3H, s, H-14). $\left.{ }^{13} \mathrm{C} \mathrm{NMR} \mathrm{(CDCl}, 100 \mathrm{MHz}, \mathrm{ppm}\right): \delta 139.17$ (C-9), 127.97 (C-8), 54.40 (C-7), 50.38 (C-5), 41.53 (C-3), 38.96 (C-10), 36.89 (C-1), 33.05 (C-14), 32.95 (C-4), 30.37 (C-6), 21.50 (C-13), 19.58 (C-15), 18.93 (C-2), 16.11 (C-12), 13.14 (C-11).

Saponification of methyl 7-hydroxyimino-homodrim-8(9)-en-12-oate (15). To a solution of ester oxime 15 $(0.3 \mathrm{~g}, 1.02 \mathrm{mmol})$ in EtOH $(10 \mathrm{~mL})$ solid $\mathrm{KOH}(1.2 \mathrm{~g})$ was added. The resulted reaction mixture was refluxed for 3 hrs, then $2 / 3$ of alcohol were distilled. The remained mixture was diluted with water $(10 \mathrm{~mL})$ and extracted with $\mathrm{Et}_{2} \mathrm{O}$ $(3 \times 10 \mathrm{~mL})$. The organic layer was washed with water $(20 \mathrm{~mL})$, dried on anhydrous sodium sulfate, concentrated, and the title compound $16(0.27 \mathrm{~g}, 95 \%$ yield $)$ was obtained, as a white solid $(\mathrm{EtOH})$, m.p. $197-199^{\circ} \mathrm{C},[\alpha]_{\mathrm{D}}^{20}=+7.4^{\circ}(c 2.3$, $\mathrm{CHCl}_{3}$ ).

IR (ATR) $v: 3239,2931,1689,1620,1422,1334,1241,1216,973,723 \mathrm{~cm}^{-1}$.

${ }^{1} \mathrm{H}$ NMR $\left(\mathrm{CDCl}_{3}, 400 \mathrm{MHz}, \mathrm{ppm}\right): \delta 12.15(1 \mathrm{H}, \mathrm{s}, \mathrm{OH}) ; 10.78(1 \mathrm{H}, \mathrm{s}, \mathrm{N}-\mathrm{OH}) ; 3.17(1 \mathrm{H}, \mathrm{d}, J 16.8 \mathrm{~Hz}, \mathrm{H}-11)$; $3.10(1 \mathrm{H}, \mathrm{d}, J 16.8 \mathrm{~Hz}, \mathrm{H}-11) ; 1.30(1 \mathrm{H}, \mathrm{d}, J 3.6 \mathrm{~Hz}, \mathrm{H}-5) ; 1.72$ (3H, s, H-13), 0.88 (9H, s, H-14, H-15, H-16). ${ }^{13} \mathrm{C}$ NMR 
(CDCl $, 100 \mathrm{MHz}, \mathrm{ppm}): \delta 172.50$ (C-12), 155.54 (C-7), 145.03 (C-9), 126.38 (C-8), 48.04 (C-5), 41.18 (C-3), 38.55 (C-10), 35.15 (C-1), 33.48 (C-11), 32.86 (C-4), 32.56 (C-15), 21.03 (C-14), 20.30 (C-6), 18.22 (C-2), 18.07 (C-16), 13.07 (C-13).

Reduction of methyl 7-hydroxyimino-homodrim-8(9)-en-12-oate (15) and 7-hydroxyimino-homodrim8(9)-en-12-oic acid (15). A solution of oximes $15(0.109 \mathrm{~g}, 0.37 \mathrm{mmol})$ or $\mathbf{1 6}(0.103 \mathrm{~g}, 0.36 \mathrm{mmol})$ in anhydrous THF $(10 \mathrm{~mL})$ was treated with $\mathrm{LiAlH}_{4}(0.14 \mathrm{~g})$. The resulted mixture was refluxed and stirred for $10 \mathrm{~h}$, then it was diluted with water $(10 \mathrm{~mL})$, and treated dropwise with $\mathrm{HCl}(10 \%, 5 \mathrm{~mL})$ until the acidic level of $\mathrm{pH}$ is reached. The aqueous layer was extracted with $\mathrm{Et}_{2} \mathrm{O}(2 \times 5 \mathrm{~mL})$, neutralized with saturated aqueous $\mathrm{Na}_{2} \mathrm{CO}_{3}$ solution $(10 \mathrm{~mL})$, and extracted with EtOAc $(3 \times 5 \mathrm{~mL})$. The organic layer was washed with water $(10 \mathrm{~mL})$ and dried. After the solvent removal, the crude product (305 $\mathrm{mg}$ and $325 \mathrm{mg})$ was purified by column chromatography on silica gel $(0.070 \mathrm{~g}$ and $0.076 \mathrm{~g}$, eluent: methanol/ $\left.\mathrm{CHCl}_{3} 2: 9\right)$ to give 7-hydroxyimino-homodrim-8(9)-en-12-ol 17 (0.054 g, 55\% and 0.058 g, 60\%), and 12-hydroxi-homodrim-8(9)-en-7-one $18(0.009 \mathrm{~g}, 10 \%$ and $0.011 \mathrm{~g}, 12 \%)$, respectively.

7-hydroxyimino-homodrim-8(9)-en-12-ol 17, as a white solid, m.p. $111-113^{\circ} \mathrm{C},[\alpha]_{\mathrm{D}}^{20}=-15.07^{\circ}\left(\mathrm{c} 0.5, \mathrm{CHCl}_{3}\right)$. IR (ATR)v : 3280, 2927, 1611, 1452, 1442, 1388, 1375, 1028, 955, $757 \mathrm{~cm}^{-1}$.

${ }^{1} \mathrm{H}$ NMR $\left(\mathrm{CDCl}_{3}, 400 \mathrm{MHz}, \mathrm{ppm}\right): \delta 10.72(1 \mathrm{H}, \mathrm{s}, \mathrm{N}-\mathrm{OH}) ; 4.66(1 \mathrm{H}, \mathrm{t}, J 5.26 \mathrm{~Hz} \mathrm{OH}) ; 1.77$ (3H, s, H-13); 0.88 (6H, s, H-14, H-16), 0.87 (3H, s, H-15). ${ }^{13} \mathrm{C}$ NMR (CDCl $\left., 100 \mathrm{MHz}, \mathrm{ppm}\right): \delta 156.08$ (C-7), 148.95 (C-9), 125.34 (C-8), 60.96 (C-12), 48.50 (C-5), 41.73 (C-3), 39.00 (C-10), 36.32 (C-1), 33.45 (C-4), 33.11 (C-15), 32.81 (C-11), 21.64 (C14), 20.83 (C-6), 18.98 (C-16), 18.85 (C-2), 13.39 (C-13).

12-hydroxy-homodrim-8(9)-en-7-one 18, as a white solid, m.p. $97-98^{\circ} \mathrm{C},[\alpha]_{\mathrm{D}}{ }^{20}=+58.0^{\circ}\left(c 0.4, \mathrm{CHCl}_{3}\right)$.

IR (ATR)v : 3456, 2979, 1664, 1455, 1392, 1380, 1145, $1074 \mathrm{~cm}^{-1}$.

${ }^{1} \mathrm{H}$ NMR ( $\left.\mathrm{CDCl}_{3}, 400 \mathrm{MHz}, \mathrm{ppm}\right): \delta 1.78$ (3H, s, H-13); 1.07 (3H, s, H-16); 0.90 (3H, s, H-14). 0.86 (3H, s, $\mathrm{H}-15),{ }^{13} \mathrm{C} \mathrm{NMR}\left(\mathrm{CDCl}_{3}, 100 \mathrm{MHz}, \mathrm{ppm}\right): \delta 200.05$ (C-7), 163.59 (C-9), 131.56 (C-8), 61.28 (C-12), 50.11 (C-5), 40.61 (C-10), 41.24 (C-3), 36.14 (C-1), 35.23 (C-6), 33.11 (C-4), 32.98 (C-11), 32.45 (C-15), 21.27 (C-14), 18.87 (C-2), 18.10 (C-16), 17.75 (C-13).

\section{Acknowledgments}

I would like to thank my supervisor Professor, Doctor Habilitatus Aculina Aricu for her guidance and kind support.

\section{References}

1. Jansen, B.J.M.; De Groot, A. Occurrence, biological activity and synthesis of drimane sesquiterpenoids. Natural Product Reports, 2004, 21, pp. 447-449.

2. Urones, J.G.; Diez, D.; Gomez, P.M.; Marcos, I.S.; Basabe, P.; Moro, R.F. Drimane homochiral semisynthesis: pereniporinA, 9-epiwarburganal and C-9 nitrogenated drimanes. Natural Product Letters, 1998, 11, pp. 145-152.

3. Barrero, A.F.; Alvarez-Manzaneda, E.J.; Chahboun, R.; Gonzalez, D.C. New Routes toward drimanes and nordrimanes from (-)-sclareol, Synlett, 2000, 11, pp. 1561-1564.

4. Zarraga, M.; Zarraga, A.M.; Rodriguez, B.; Perez, C.; Paz, C.; Paz, P.; Sanhueza C. Synthesis of a new nitrogenated drimane derivative with antifungal activity. Tetrahedron Letters, 2008, 49, pp. 4775-4776.

5. Kuchkova, K.; Aricu, A.; Vlad, P. Synthesis of 11-aminodrim-7-ene from drimenol. Chemistry of Natural Compounds, 2009, 45(3), pp. 367-370.

6. Aricu, A. Synthesis of nitrogen-containing compounds from higher terpenoids. Chemistry Journal of Moldova, 2011, 6(1), pp. 10-28.

7. Kuchkova, K.; Aricu, A.; Barba, A.; Secara, E.; Vlad, P.; Ungur N. Synthesis of 12-amino-11-dihomodrimane sesquiterpenoids from norambreinolide. Chemistry of Natural Compounds, 2014, 50, pp. 458-461.

8. Kuchkova, K.; Aricu, A.; Secara, E.; Barba, A.; Dragalin, I.; Vlad, P.; Ungur, N. Synthesis of 13-amino-14,15dinorlabd-8(9)-ene from sclareol. Russian Chemical Bulletin, 2014, 63, pp. 2074-2076.

9. Vlad, P.; Edu, C.; Koltsa, M.; Ciocarlan, A.; Nicolescu, A.; Deleanu, C. Enantioselective synthesis of 11-homodrim7-en-9 $\alpha, 12,13$-triol. Chemistry of Natural Compounds, 2011, 47(4), pp. 574-578.

10. Vlad, P.; Vorob'eva, E. Synthesis of drim-8-en-7-one. Chemistry of Natural Compounds, 1983, 19, pp. 139-141 (in Russian).

11. Kuchkova, K.; Aricu, A.; Barba, A.; Vlad, P.; Lipkovskii, Ya.; Simonov, Yu.; Kravtsov, V. Synthesis of nitrogencontaining drimane sesquiterpenoids from 11-dihomodrim-8(9)-en-12-one. Chemistry of Natural Compounds, 2011, 47(2), pp. 223-228. 